\title{
The Two Conserved Cysteine Residues of the Triple Gene Block Protein 2 Are Critical for Both Cell-to-Cell and Systemic Movement of Bamboo mosaic virus
}

\author{
Yang-Hao Tseng, ${ }^{1}$ Hsiu-Ting Hsu, ${ }^{1}$ Yuan-Lin Chou, ${ }^{1}$ Chung-Chi Hu, ${ }^{2}$ Na-Sheng Lin, ${ }^{3}$ Yau-Heiu Hsu, ${ }^{2}$ \\ and Ban-Yang Chang ${ }^{1}$ \\ ${ }^{1}$ Institute of Biochemistry and ${ }^{2}$ Graduate Institute of Biotechnology, National Chung-Hsing University, Taichung 40227, \\ Taiwan, Republic of China; ${ }^{3}$ Institute of Plant and Microbial Biology, Academia Sinica, Nankang, Taipei 11529, Taiwan, \\ Republic of China
}

Submitted 24 March 2009. Accepted 5 July 2009.

\begin{abstract}
The triple gene block protein 2 (TGBp2) of Bamboo mosaic virus (BaMV) is a transmembrane protein which is known to be required for the cell-to-cell movement of potexviruses. This protein has two conserved Cys residues, Cys109 and Cys-112, at its C-terminal tail, which is supposed to be exposed on the outer surface of the endoplasmic reticulum (ER) membrane and ER-derived granular vesicles. In this study, we investigated the importance of these two Cys residues on the cell-to-cell and systemic movement of BaMV. Our results indicate that the Cys-to-Ala substitutions in TGBp2 make the cell-to-cell movement of BaMV relatively inefficient and the systemic movement of BaMV severely inhibited. Moreover, the defect in systemic movement is attributed to the inefficient transport of viral RNA in the phloem of petiole. Clearly, TGBp2 is critical not only for the cell-to-cell but also for the systemic movement of BaMV. In addition, the conserved Cys residues are important for the functioning of TGBp2.
\end{abstract}

Plant viruses spread from cell to cell through the plasmodesmata (PD) and systemically through the sieve tube of the host plant. The transport of plant viruses from cell to cell requires the assistance of movement proteins (MP) (Carrington et al. 1996; Morozov and Solovyev 2003). Some plant viruses require one virus-encoded MP, which binds nonspecifically to singlestranded viral RNA, for transport (Citovsky et al. 1990, 1992). However, some require three MP encoded by the module called triple gene block (TGB) for transport. The three MP are named TGBp1, TGBp2, and TGBp3 according to their positions in the module (Morozov et al. 1989; Solovyev et al. 1996).

Viruses containing the TGB module are classified into hordei-like and potex-like viruses. The former comprises rodshaped viruses of the genera Hordeivirus, Pomovirus, Pecluvirus, and Benyvirus. They do not require capsid protein (CP) for cell-to-cell movement (Quillet et al. 1989; Petty et al. 1990). The latter is composed of filamentous viruses of the genera Potexvirus, Foveavirus, Carlavirus, and Allexivirus (Morozov and Solovyev 2003). However, CP is required for cell-to-cell movement of these viruses (Chapman et al. 1992; Forster et al. 1992; Lough et al. 2000).

Corresponding authors: B.-Y. Chang; E. mail: bychang@mail.nchu.edu.tw or Y.-H. Hsu; E-mail: yhhsu@ dragon.nchu.edu.tw
The subcellular localizations and functions of TGB proteins have been studied. TGBp1 is mainly associated with cytoplasmic inclusions in virus-infected tissues (Davies et al. 1993; Rouleau et al. 1994; Chang et al. 1997; Hsu et al. 2004). It is a multifunctional protein that is able to induce an increase in the size-exclusion limit (SEL) of PD (Angell et al. 1996; Lough et al. 1998, 2000), bind viral single-stranded RNA (Kalinina et al. 1996; Lough et al. 1998; Wung et al. 1999), form ribonucleoprotein (RNP) complex with viral nucleic acids (Lough et al. 2000), exhibit NTPase (Kalinina et al. 1996; Morozov et al. 1999; Liou et al. 2000) and RNA helicase activities (Kalinina et al. 2002), and interact with viral particles to change its conformation from a nontranslatable into a translatable form (Atabekov et al. 2000). It has been also reported to be a suppressor for gene silencing which is necessary, but not sufficient, for cell-to-cell movement of viral nucleic acid through the PD (Voinnet et al. 2000; Bayne et al. 2005).

TGBp2 and TGBp3 are endoplasmic reticulum (ER)-associated proteins (Krishnamurthy et al. 2003; Mitra et al. 2003; Ju et al. 2005). On the basis of amino acid sequence analyses, it is assumed that the TGBp2 of potex-like viruses are transmembrane proteins, with the central conserved segment lying in the ER lumen and the short $\mathrm{N}$ - and $\mathrm{C}$-terminal tails exposed on the outer surface of proteoliposomes purified from the virusinfected tissues (Mitra et al. 2003; Hsu et al. 2008). TGBp2 is able to induce the formation of granular vesicles derived from the ER, which align on the actin network during virus infection (Ju et al. 2005). Deletion or substitution of the highly conserved amino acid residues in the central segment of TGBp2 causes it to associate with the enlarged vesicles of ER and inhibit cell-to-cell movement of the virus, indicating that the formation of normal TGBp2-containing granular vesicles is crucial for viral cell-to-cell movement (Ju et al. 2007). However, it remains unclear whether TGBp2 also participates in systemic (or long-distance) movement of the virus.

TGBp3 has a transmembrane N-terminal domain and a cytosolic C-terminal domain (Krishnamurthy et al. 2003). It is localized to the ER-derived peripheral bodies associated with the PD (Solovyev et al. 2000; Zamyatnin et al. 2002; Gorshkova et al. 2003) and to the tubular ER network, nucleus, granular bodies, and perinuclear aggregate during virus infection $(\mathrm{Ju}$ et al. 2008). Moreover, it is required for targeting of TGBp2 to the peripheral bodies (Solovyev et al. 2000; Haupt et al. 2005). The inhibition of viral cell-to-cell movement by mutations pre- 
venting ER association of TGBp2 or TGBp3 indicates that the ER association is important for the functioning of both proteins (Krishnamurthy et al. 2003; Mitra et al. 2003).

We have planned to answer where and how TGBp2 functions to assist the movement of viral RNA during viral infection. To start with, we searched for conserved amino acid residues at both the $\mathrm{N}$ - and $\mathrm{C}$-terminal tails of TGBp2. These amino acid residues are supposed to be exposed on the outer surface of the ER membrane and the ER-derived granular vesicles (Hsu et al. 2008) and have a potential to interact with viral RNP (Haupt et al. 2005; Hsu et al. 2008). Two conserved Cys residues, Cys-109 and Cys-112, at the C-terminal tail of TGBp2 were identified (Fig. 1). Here, we report that replacement of either one or both of the Cys residues with Ala significantly affects the cell-to-cell movement and systemic movement of Bamboo mosaic virus (BaMV).

\section{RESULTS}

The substitutions of conserved Cys-109 or Cys-112 by alanine in TGBp2 reduce the infectivity of BaMV.

To explore the roles of the two conserved Cys residues at the C-terminal tail of TGBp2 (Fig. 1) during viral infection, three mutant BaMV, each having either one or both of the conserved cysteine residues in TGBp2 being replaced with alanine, were constructed (discussed below). The three mutant clones (pGC109A, pGC112A, and pGC109, 112A) and the two wildtype (WT) clones (pCB and pCBG) of BaMV (Fig. 2A) were then inoculated onto the leaves of Chenopodium quinoa and
Nicotiana benthamiana, respectively. The disease symptoms or the abilities of viruses to spread in leaves were then analyzed. Because all of the WT (pCBG) and mutant BaMV contain an expressible green fluorescent protein $(g f p)$ gene between the coding sequences of TGBp3 and CP in the genome, we expected to see spread of green fluorescence in inoculated leaves if the tested BaMV is able to replicate and move from cell to cell. The green fluorescence spread in the inoculated leaves was examined 6 days postinoculation (dpi) for $C$. quinoa and $17 \mathrm{dpi}$ for $N$. benthamiana. Disease symptoms and the spread of green fluorescence were observed on the leaves inoculated with each of the BaMV (Fig. 2B and C), although the disease symptoms and the spread of fluorescence were weaker on the leaves inoculated with the mutant BaMV, especially that with the Cys-109, 112-Ala substitutions. Moreover, the BaMV $\mathrm{CP}$ was easily detected in $C$. quinoa and $N$. benthamiana leaves inoculated with each of the tested viruses (Fig. 2D and E). No reversion of the Cys-to-Ala substitution in TGBp2 was observed (data not shown) as the genomes of the mutant BaMV were sequenced at the region coding for TGBp2 after reverse-transcription polymerase chain reaction (RT-PCR); therefore, we thought that the mutant BaMV are able to move and proliferate in the infected tissues. Thus, the weaker green fluorescence spread (or the reduced infectivity) of the mutant BaMV must be attributed to the defects of the mutant BaMV either in replication or in expression of a functional TGBp2.

To investigate the cause of the reduced infectivity of the mutant BaMV, we first checked the replication efficiency of the mutant BaMV. The full-length genomic RNA of BaMV in $N$.

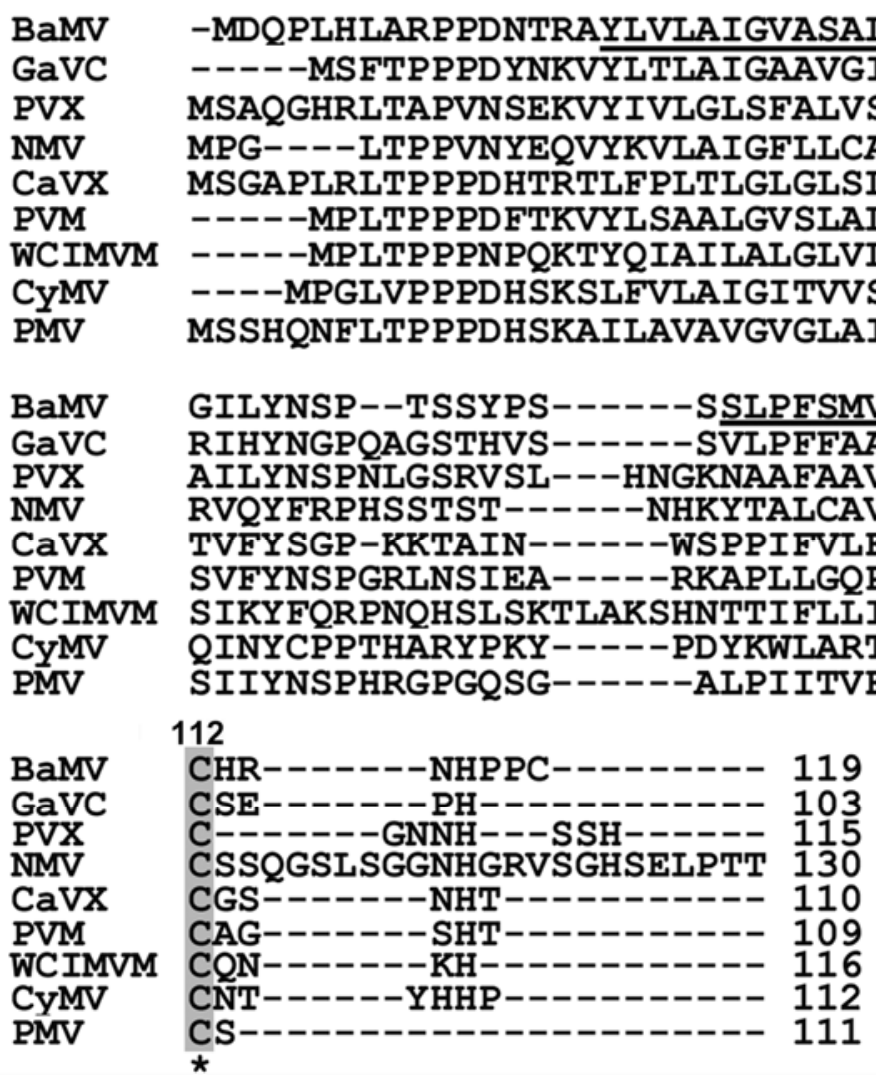

Fig. 1. Amino acid sequence alignment of triple gene block protein 2 (TGBp2) of potexviruses. The amino acid sequences of TGBp2 of the nine potexviruses being aligned using ClustalW were obtained from the database of the National Center for Biotechnology Information (NCBI). The potexviruses include Bamboo mosaic virus (BaMV) (AAB70564), Garlic virus C (GaVC) (BAA61820), Potato virus X (PVX) (BAA00251), Narcissus mosaic virus (NMV) (NP_040780), Cactus virus X (CaVX) (NP_148782), Potato virus $M$ (PVM) (NP_056769), White clover mosaic virus M (WCIMVM) (P09500), Cymbidium mosaic virus (CyMV) (AAB71855), and Papaya mosaic virus (PMV) (NP_044332). The conserved Cys residues are highlighted in gray and marked with stars below the alignment. The two conserved Cys residues of BaMV TGBp2 are located at positions 109 and 112 of the protein. The two transmembrane helices of BaMV TGBp2 as predicted by ExPASy proteomic tools with the program HMMTOP 2.0 are underlined. 
benthamiana protoplasts infected with either the WT or the mutant BaMV was analyzed by Northern blot. The contents of genomic RNA for the WT and the three mutant BaMV harboring Cys-109-Ala, Cys-112-Ala, Cys-109, and 112-Ala substitutions in TGBp2, respectively, were of approximately the same level (100.0, 98.1, 101.3, and 104.1\%, respectively) (Fig. 3). These results indicated that the WT and mutant BaMV possess similar replication efficiency. In other words, the reduced infectivity of the mutant BaMV may be attributed to their defects in expression of a functional TGBp2.

\section{The Cys-to-Ala substitution does not significantly affect the expression of TGBp2.}

To further answer how the Cys-to-Ala substitution reduced the infectivity of the mutant BaMV, we examined the expression of TGBp2 in protoplasts infected with the WT or one of the mutant BaMV because the content of MP has been reported to affect the efficiency of the cell-to-cell and systemic movement of plant virus (Arce-Johnson et al. 1995). However, the content of TGBp2 in the BaMV-infected protoplasts was too low to be detected. Therefore, we examined the relative content of TGBp2 in the membrane fraction (P30) of $N$. benthamiana leaves inoculated with the sap prepared from the BaMV-infected leaves when the disease symptoms were apparent on systemic leaves of $N$. benthamiana infected with pCBG. Significant amounts of monomeric (M), dimeric (D), trimeric (Tr), and tetrameric (Te) TGBp2, interacting with the precleaned anti-TGBp2, were observed 16 dpi in P30 of leaves inoculated with the WT (pCBG.) or mutant BaMV (pGC109A or pGC112A) bearing a single Cys-to-Ala substitution in TGBp2 (Fig. 2F). However, no TGBp2 was detected in P30 of leaves inoculated with pGC109, 112A. The TGBp2 containing Cys-109, 112-Ala substitutions could be detected a few days later (19 dpi); thereafter, it was significantly degraded (25 dpi). Because the relative content of TGBp2 in $\mathrm{P} 30$ of the leaves inoculated with pCBG, pGC109A, or pGC112A was similar after normalization with $\mathrm{CP}$, we inferred that the expression of TGBp2 in infected tissues is not significantly affected by the Cys-to-Ala substitution. In other words, it is the effect of the Cys-to-Ala substitution in TGBp2 on viral movement which is responsible for the reduced infectivity of the mutant BaMV.
A

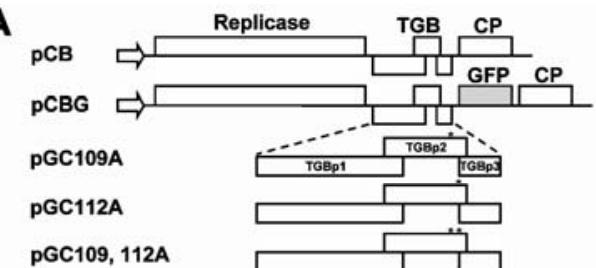

B

pGC109, 112A

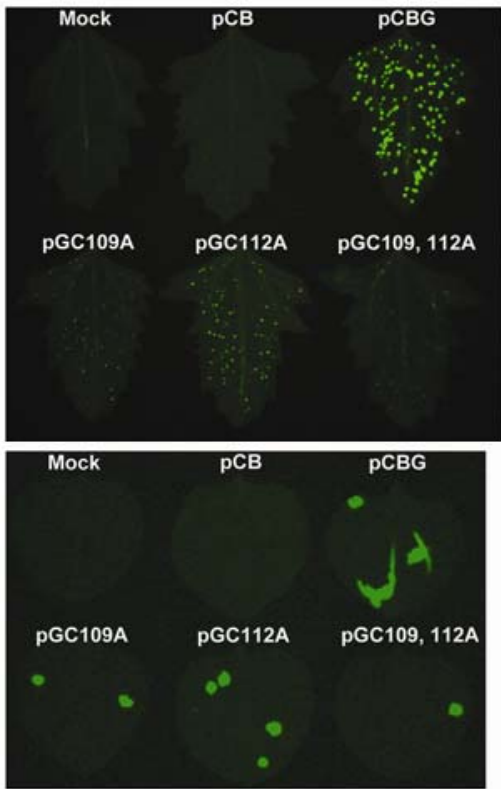

$\mathbf{F}$
D

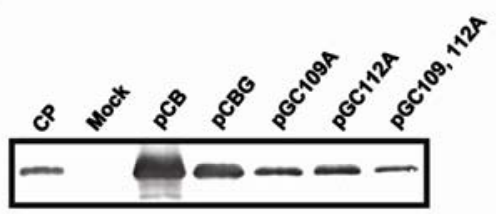

E
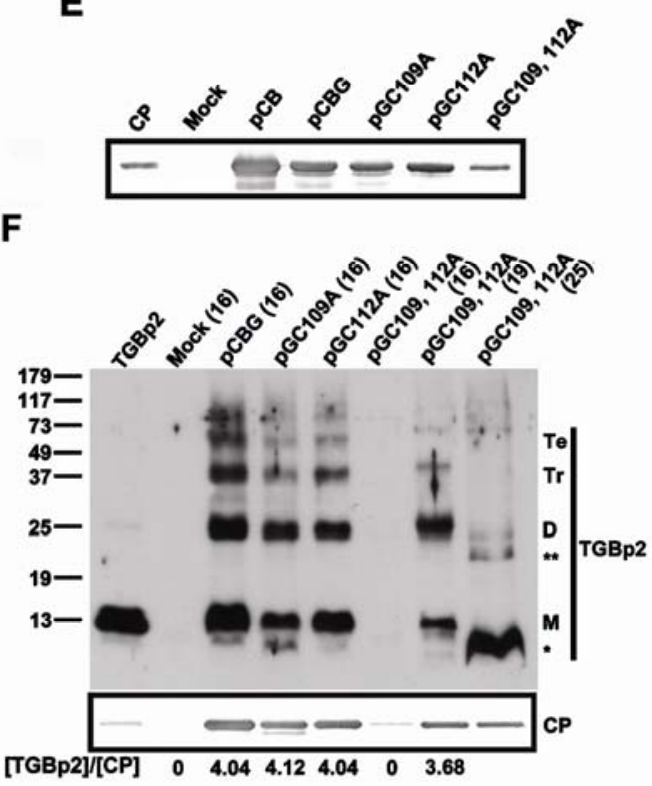

Fig. 2. Fluorescence images and Western blot analyses of Chenopodium quinoa and Nicotiana benthamiana leaves inoculated with the plasmid clones of BaMV. A, Diagrammatic representation of the infectious plasmid clones of the wild-type (WT) and mutant Bamboo mosaic virus (BaMV). Each of the infectious clones of BaMV contains a full-length BaMV genome inserted downstream the Cauliflower mosaic virus (CaMV) $35 \mathrm{~S}$ promoter (indicated by white arrow). The white boxes in the schematics represent the coding sequences of BaMV while the gray box represents the coding sequence of green fluorescent protein (GFP). The plasmids pCB and pCBG are the infectious clones of the WT BaMV and GFP-tagged WT BaMV, respectively, while pGC109A, pGC112A, and pGC109, 112A are the plasmid clones of mutant BaMV. The Cys-to-Ala substitutions at positions 109 and 112 of triple gene block protein 2 (TGBp2) were indicated by asterisks. B and $\mathbf{C}$, Images of infected leaves were taken at $\mathbf{B}, 6$ days postinoculation (dpi) for $C$. quinoa and $\mathbf{C}, 17 \mathrm{dpi}$ for $N$. benthamiana. Mock indicates the inoculation of C. quinoa and N. benthamiana leaves with water. The total proteins extracted from the inoculated leaves of $\mathbf{D}$, C. quinoa $10 \mathrm{dpi}$ and $\mathbf{E}, N$. benthamiana 17 dpi were separated in a $12 \%$ sodium dodecyl sulfate polyacrylamide gel, blotted onto the polyvinylidene diflouride membrane, and probed with polyclonal antiserum against capsid protein (CP). The CP in the left-most lane of D and E was purified from the Escherichia coli overexpression system. Protein samples equivalent to $80 \mu \mathrm{g}$ of the inoculated leaves were used. F, Content of TGBp2 relative to CP in $N$. benthamiana leaves inoculated with the sap prepared from WT and mutant BaMV-infected tissues. The amount of proteins loaded was equivalent to $0.238 \mathrm{~g}$ or $0.267 \mathrm{mg}$ of leaf tissues for immunological analysis of TGBp2 or CP, respectively. The contents of TGBp2 in monomeric, dimeric, and trimeric forms as well as the content of CP were measured with Multi Gauge V3.0 software supplied by FUJIFILM. Shown on the left margin are the molecular masses (in $\mathrm{kDa}$ ) of protein markers. The degraded forms of TGBp2 are indicated by * or **. The TGBp2 in the left-most lane of the top panel was purified from the E. coli overexpression system; the CP in the left-most lane of the bottom panel was the same as that depicted for $\mathrm{D}$ and $\mathrm{E}$. Numbers in the parentheses represent days postinoculation with the sap. 
To confirm the above idea, the activities of cell-to-cell movement, as denoted by the average diameter of fluorescent foci, of the WT and mutant BaMV within the epidermal cells of $C$. quinoa were examined with an Olympus BX51 epifluorescence microscope at $6 \mathrm{dpi}$. In three independent experiments, the average diameter of fluorescent foci induced by each of the mutant BaMV was at least twofold smaller than that induced

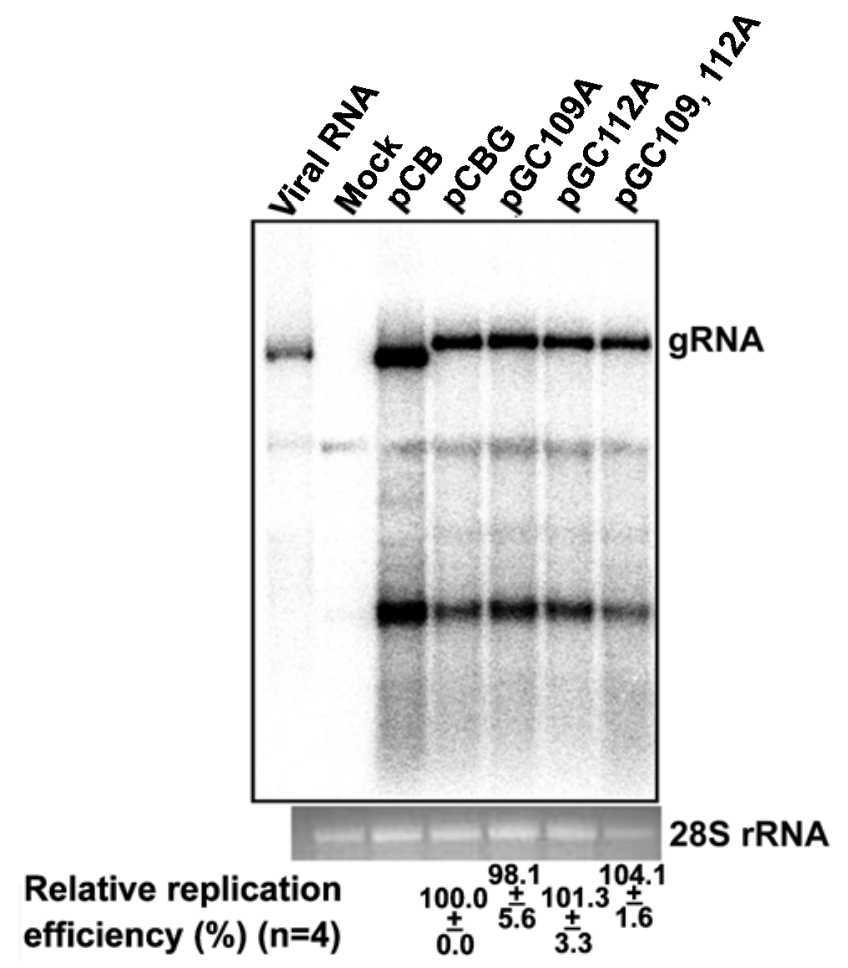

Fig. 3. Northern blot analyses of viral RNA in the protoplasts of Nicotiana benthamiana. Total nucleic acids extracted from the protoplasts inoculated with indicated plasmid clone of Bamboo mosaic virus (BaMV) at $48 \mathrm{~h}$ postinoculation were separated in a $1.2 \%$ agarose gel, blotted onto a nylon membrane, and probed with ${ }^{32} \mathrm{P}$-labeled RNA transcript complementary to the $3^{\prime}$ end of the BaMV genomic RNA (Cheng and Tsai 1999). Viral RNA in the left-most lane was purified from Chenopodium quinoa inoculated with the plasmid clone of wild-type (WT) BaMV, pCB. The contents of the full-length genomic RNA (gRNA) and the internal control (28S ribosomal RNA [rRNA]) as well as the relative replication efficiencies of the $\mathrm{WT}$ and the mutant BaMV are shown in the right and bottom margins. The content of gRNA relative to that of 28S rRNA in protoplasts infected with the WT (pCBG) or one of the mutant BaMV was calculated from WT and mutant BaMV-infected tissues. The amount of proteins loaded was equivalent to $0.238 \mathrm{~g}$ or $0.267 \mathrm{mg}$ of leaf tissues for immunological analysis of triple gene block protein 2 or capsid protein, respectively. The relative replication efficiency is an averaged value of four independent experiments. by the WT (Fig. 4). In addition, the difference in average diameter of fluorescent foci was also significant between the WT and each of the mutant BaMV, as well as among the mutant BaMV as revealed by analysis of variance $(P<0.05)$. Thus, the Cys-to-Ala substitutions in TGBp2 renders the cell-to-cell movement of BaMV inefficient.

\section{The mutant BaMV are also defective in systemic movement.}

In addition to the effects of Cys-to-Ala substitutions in TGBp2 on cell-to-cell movement of BaMV, the effects of the same substitutions on systemic movement of BaMV were also examined. To inspect the systemic movement of BaMV, the emergence of green fluorescence on the upper uninoculated (or systemic) leaves of $N$. benthamiana was examined 23 and 32 dpi of the lower leaves with BaMV. No green fluorescence was observed in the systemic leaves of $N$. benthamiana (Fig. 5A and $\mathrm{B}$ ) inoculated with each of the mutant BaMV, suggesting that the Cys-to-Ala substitution in TGBp2 had affected the systemic movement of BaMV. To confirm this idea, we analyzed whether there is $\mathrm{CP}$ in the systemic leaves of $N$. benthamiana by Western blot. No CP was found even though the amount of systemic leaves used for the Western analysis was increased from $400 \mu \mathrm{g}$ to $7.2 \mathrm{mg}$ (Fig. 5C and D), further supporting the idea that the mutant BaMV are unable to infect $N$. benthamiana in a systemic manner.

However, to eliminate the possibility that this defect was due to the low infectivity of the infectious plasmid clones of BaMV, leaves of $N$. benthamiana were inoculated with the sap prepared from the BaMV-infected leaves. Again, no green fluorescence spread or $\mathrm{CP}$ was observed in the systemic leaves of $N$. benthamiana (Fig. 6B, C, E, and F), although the spread of green fluorescence and disease symptoms were obvious in the inoculated leaves (Fig. 6A). Taken together, these results indicated that the mutant BaMV with Cys-to-Ala substitutions in TGBp2 are unable to move systemically.

\section{The mutant BaMV move inefficiently}

\section{in the phloem of the petiole.}

The ability of the mutant BaMV to move from cell to cell led us to speculate that the defect in systemic movement of the mutant BaMV is attributed to their inabilities to enter into, move inside, or exit from the phloem of vein, petiole, or stem of the infected host. To test these possibilities, the N. benthamiana leaves were inoculated with the WT or one of the mutant BaMV and the spread of green fluorescence from the inoculated to systemic leaves in the regions, blade (I1), junction between blade and petiole (I2), petiole (P), stem (SB and ST), and systemic leaf (Sy) was examined 15, 20, and 25 dpi. The spread of green fluorescence was clear throughout the

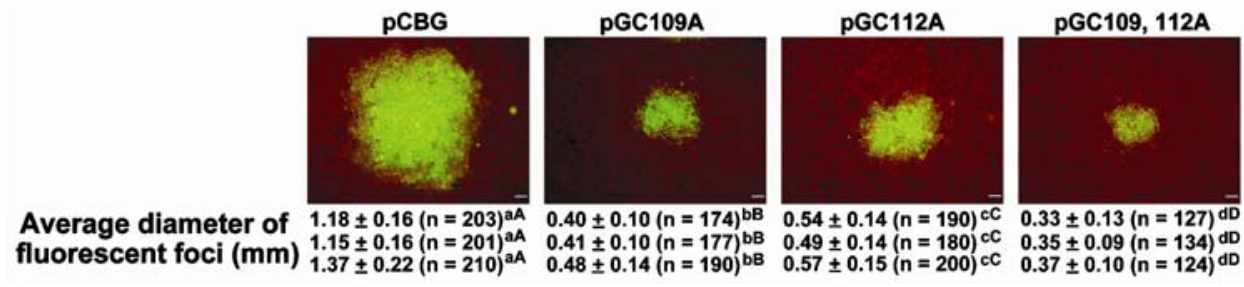

Fig. 4. Cell-to-cell movement of Bamboo mosaic virus (BaMV). Fluorescent images of the epidermal cells of Chenopodium quinoa leaves inoculated with the plasmid clone of wild-type (WT) BaMV (pCBG) or one of the three mutant BaMV (pGC109A, pGC112A, or pGC109, 112A) were taken at 6 days postinoculation. The average diameter of fluorescent foci after infection with the WT or one of the mutant BaMV was measured and shown as millimeter $(\mathrm{mm}) \pm$ standard deviation. The total number of green fluorescent spots examined on approximately three to four leaves infected with each BaMV is indicated in parentheses. The average diameters of fluorescent foci measured for all of the tested BaMV in three independent experiments were examined using analysis of variance (ANOVA). Averages within the same column with the same small letter are not significantly different at $P>0.05$. Averages within the same row with different capital letters are of a statistically significant difference on the basis of the results of ANOVA at $P<0.05$. The white bar shown in bottom right corner is equal to $100 \mu \mathrm{m}$. 
infection route (I1, I2, P, SB, ST, and Sy) in $N$. benthamiana 15, 20, and 25 dpi with the WT BaMV (pCBG) (Fig. 7). However, the spread of green fluorescence was restricted to I1 of the leaves 15 dpi with any one of the mutant BaMV (pGC109A,
pGC112A, or pGC109, 112A). Not until 20 dpi was the green fluorescence spread, from the blade to the junction between the blade and the petiole (I2), and to approximately one-fifth to onehalf the length of the internal phloem of the petiole $(\mathrm{P})$,
A
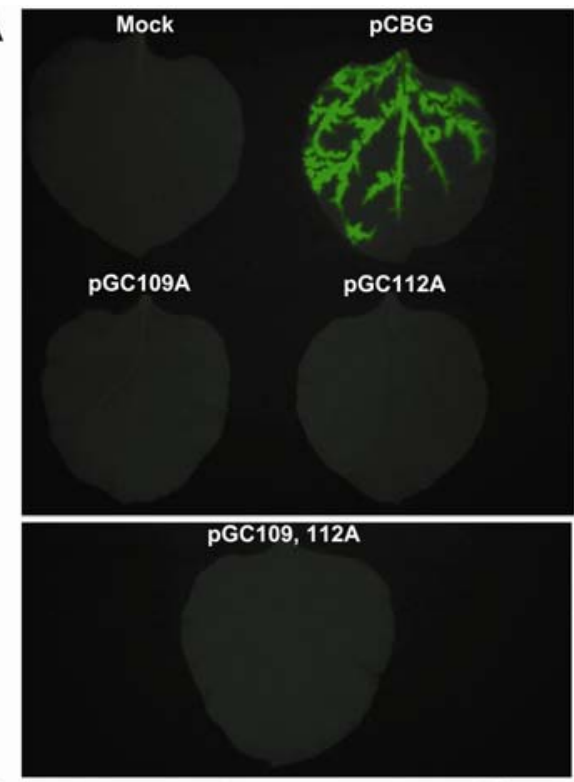

C

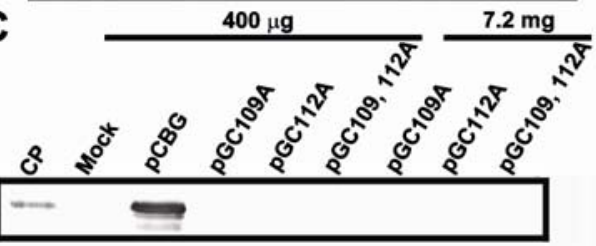

B

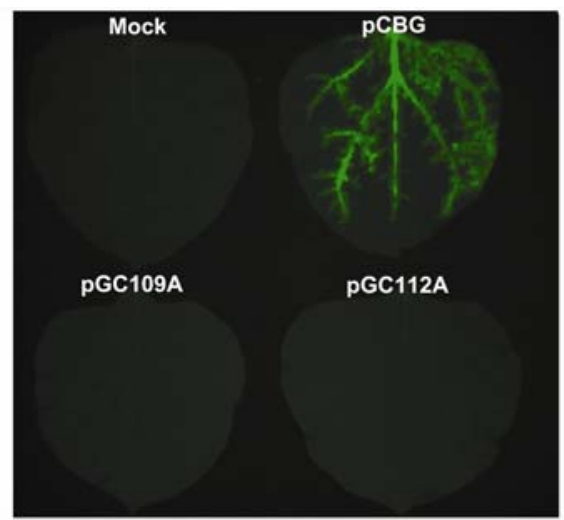

pGC109, 112A
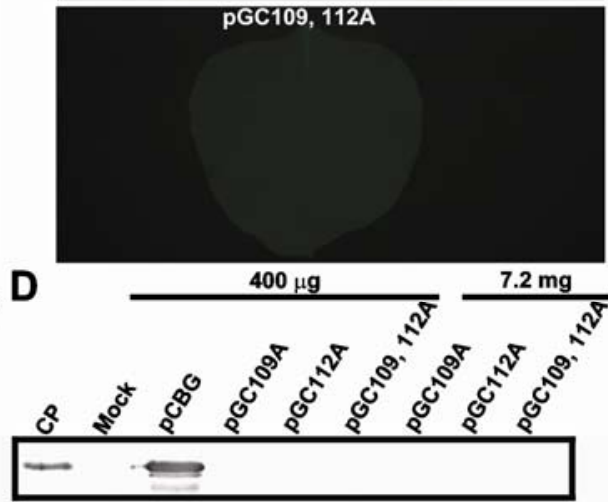

Fig. 5. Examination of the systemic spread of Bamboo mosaic virus (BaMV). Fluorescent images of the upper uninoculated leaves of Nicotiana benthamiana were taken at $\mathbf{A}, 23$ and $\mathbf{B}, 32$ days postinoculation of the lower leaves with water (Mock), the plasmid clone of wild-type BaMV (pCBG), and each of the three mutant clones of BaMV (pGC109A, pGC112A, and pGC109, 112A). The total proteins extracted from the upper uninoculated leaves of $N$. benthamiana C, 23 and D, 32 dpi were subjected to sodium dodecyl sulfate polyacrylamide gel electrophoresis and analyzed with anti-capsid protein (CP). The CP in the left-most lane of C and D was purified from the Escherichia coli overexpression system. Protein samples equivalent to $400 \mu \mathrm{g}$ or $7.2 \mathrm{mg}$ of the upper uninoculated leaves were used.

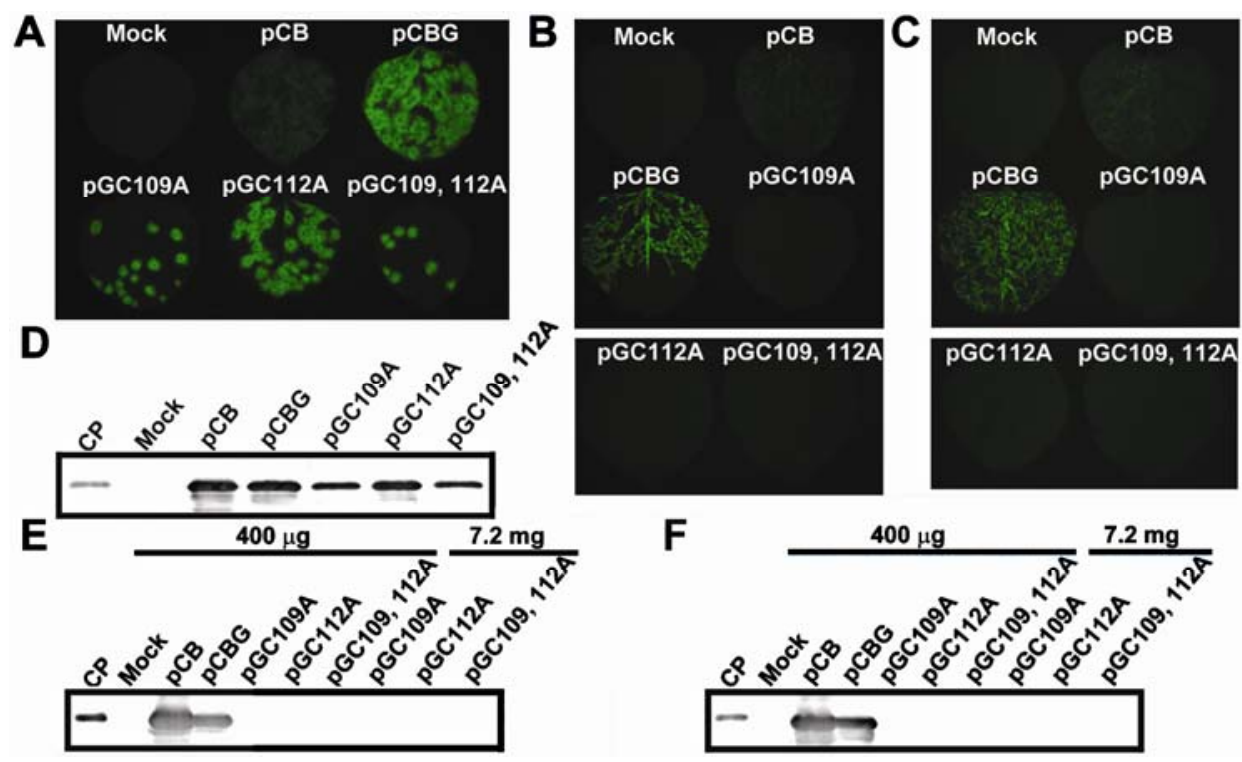

Fig. 6. Systemic movement of Bamboo mosaic virus (BaMV). A, Fluorescent images of the inoculated leaves of Nicotiana benthamiana were taken at 17 days postinoculation (dpi) with the sap prepared from the BaMV-infected leaves. Fluorescent images of the systemic leaves of $N$. benthamiana were taken B, 23 and $\mathbf{C}, 32 \mathrm{dpi}$. D, E, and $\mathbf{F}$, Western blot analyses of $\mathrm{CP}$ in the inoculated and systemic leaves of $N$. benthamiana. The total proteins were extracted from D, inoculated leaves and systemic leaves of $N$. benthamiana at E, 23 and F, 32 dpi and separated in a 12\% sodium dodecyl sulfate polyacrylamide gel, blotted and probed with anti-capsid protein. The amounts of proteins loaded were equivalent to $80 \mu \mathrm{g}$ of the inoculated leaves and to $400 \mu \mathrm{g}$ or $7.2 \mathrm{mg}$ of the systemic leaves. 
observed in approximately 33 and $55 \%$ of the leaves inoculated with pGC109A and pGC112A, respectively. The spread of green fluorescence in the internal phloem of the petiole was also inhibited for plants inoculated with these two mutant BaMV; it moved only to approximately two-thirds to three-fourths the length of the petiole 5 days later. Much slower systemic movement was observed for the BaMV containing Cys-109, 112-Ala substitutions in TGBp2. The green fluorescence was nearly all (approximately 90\%) confined to the blade (I1) severely infected with the virus during the course of examination ( $25 \mathrm{dpi}$ ) in three independent experiments. These results revealed that the mutant BaMV with Cys-to-Ala substitutions in TGBp2 are unable to move efficiently from infected mesophyll to the vascular system of veins or in the phloem of the petiole.
To distinguish between the above two possibilities, we examined whether there is GFP signal in the transverse sections of the midrib and its surrounding mesophyll ( $\mathrm{Im})$, the junction between the blade and petiole (I2), and the midway petiole (P) of the leaves inoculated with BaMV. The GFP signal was easily observed in the vascular system of midrib and its surrounding mesophyll when the epidermis were inoculated with the WT (pCBG) or with the mutant BaMV (pGC109A, pGC112A or pGC109, 112A) (Fig. 8), indicating that both the WT and mutant BaMV are able to move from the mesophyll to the vascular system of the blade. The GFP signal was also observable in the junction between the blade and petiole and in the midway petiole when the leaf was inoculated with the WT or the mutant BaMV having a single Cys-to-Ala substitution, although

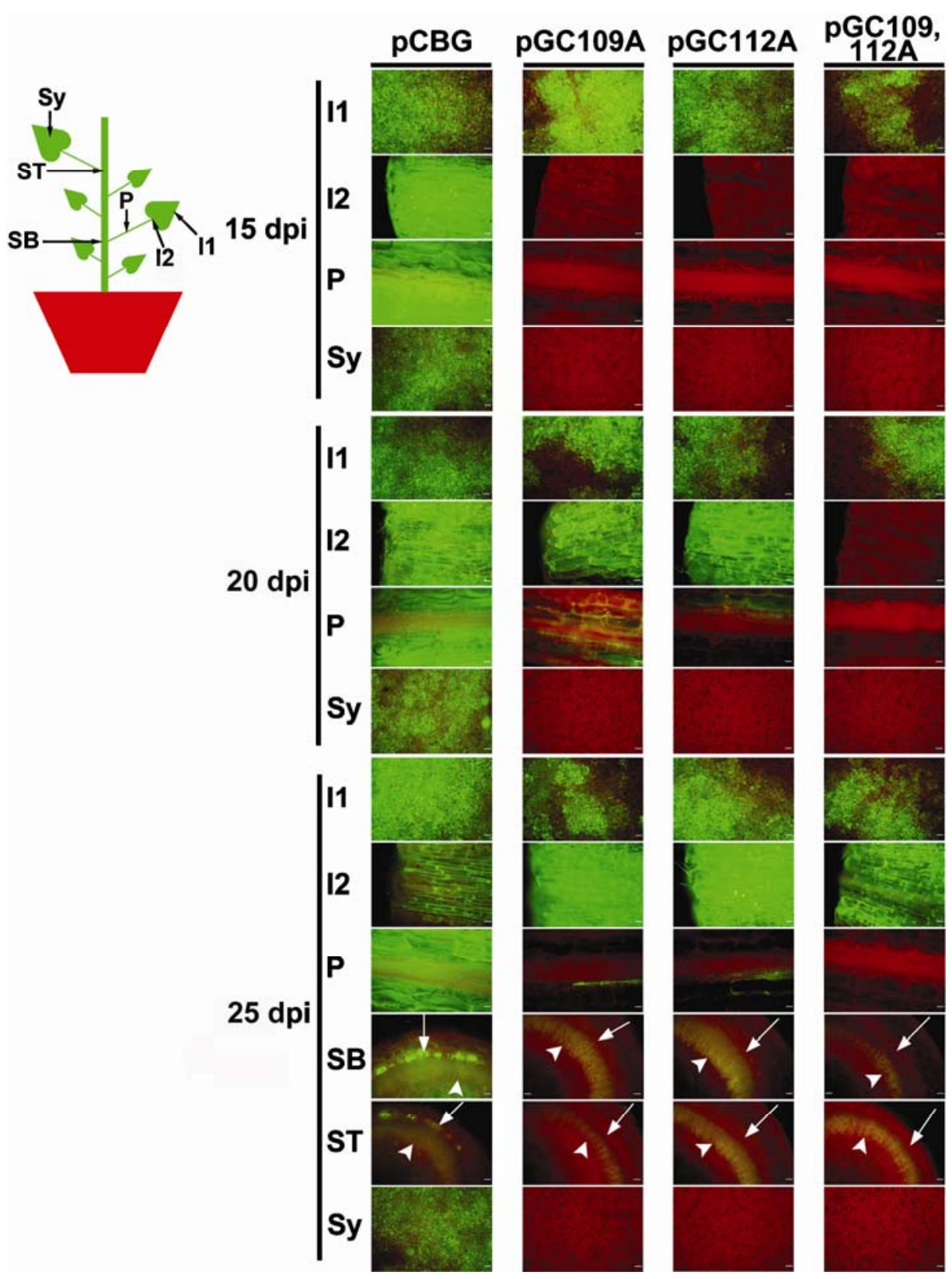

Fig. 7. Examination of the systemic movement of Bamboo mosaic virus (BaMV). The plasmid clones used to inoculate the leaves of Nicotiana benthamiana are indicated in the top margin. The designations of tissues of $N$. benthamiana being analyzed are indicated in the top left margin of the fluorescence images. I1, the epidermal cells of the blade of inoculated leaf; I2, the junction between the blade and petiole; P, vertical section of petiole; SB, cross-section of the bottom of stem; ST, cross-section of the top of stem; Sy, systemic leaf. Green fluorescent protein (GFP) fluorescence in the internal phloem of the petiole (P) is shown. Arrows point to examples of GFP fluorescence in the external phloem of stem (SB and ST) and arrowheads point to the xylem vessels of stem (SB and ST). The xylem vessels exhibit distinct yellow autofluorescence in all live sections; 15, 20, and 25 days post-inoculation (dpi) are shown in the left margin. The white bars shown in the bottom right corner of all images represent $100 \mu \mathrm{m}$. 
the spread of GFP or the mutant BaMV in the midway petiole was less efficient than the spread of the WT BaMV. However, no GFP signal was detected in the transverse section of the junction between the blade and petiole and of the midway petiole when the leaf was inoculated with the mutant BaMV containing double Cys-to-Ala substitutions. Taken together, these results indicated that the Cys-to-Ala substitutions in TGBp2 do not significantly affect the movement of BaMV from mesophyll to the vascular system of the blade; however, they, especially the Cys-109, 112-Ala substitutions, make the systemic movement of BaMV in the vascular system and the movement of BaMV between the vascular system and other tissues of the petiole inefficient.

\section{DISCUSSION}

We demonstrated that replacement of the conserved Cys residues, Cys-109 and Cys-112, in TGBp2 with Ala renders the cellto-cell movement of BaMV inefficient and the systemic movement of BaMV severely inhibited. Moreover, the inhibition of the systemic movement of BaMV resulted from the inefficiency of the mutant BaMV to move in the phloem of the petiole.

The effect of the Cys-to-Ala substitution in TGBp2 on the movement of BaMV (Fig. 4) and the indication that TGBp2 functions in endocytic recycling (Haupt et al. 2005) suggest that the two conserved Cys residues exposed on the outer surface of the ER membrane and ER-derived granular vesicles (Morozov and Solovyev 2003; Hsu et al. 2008) play a role in protein-protein or protein-nucleic acid interactions during the movement of viral RNA. However, they are unlikely to be directly involved in interaction with viral RNA because the Cysto-Ala substitution does not significantly affect the RNA-binding activity of TGBp2 (data not shown). Probably, they are required for the formation of disulfide linkage among the membrane-associated TGBp2 (Hsu et al. 2008), which is critical for TGBp2 to function. The ability of TGBp2 to be targeted to peripheral bodies by TGBp3 (Solovyev et al. 2000; Haupt et al. 2005) and the existence of a direct interaction between TGBp2 and TGBp3 (Cowan et al. 2002) raises the possibility that TGBp2 also links to TGBp3 during the virus transport. The assumption that TGBp2 and TGBp3 are functioning to facilitate the delivery of the TGBp1/CP-containing viral RNP to the PD (Morozov and Solovyev 2003) suggests that TGBp2 or TGBp2 and TGBp3 interact with TGBp1 or CP in the viral RNP. However, all the above possibilities remain to be proven.

The effect of the Cys-to-Ala substitution in TGBp2 on the movement of BaMV (Fig. 4) can also be ascribed to the defect of mutant TGBp2 in interacting with the host proteins. Evidence supporting this idea includes i) the finding of three TGBp2-interacting host proteins (TIP1, TIP2, and TIP3) that are able to interact with $\beta$-1,3-glucanase to regulate both callose degradation and the SEL of the PD, thus affecting virus movement (Wolf et al. 1991; Iglesias and Meins 2000; Bucher et al. 2001; Fridborg et al. 2003), and ii) the finding of a DNAJ-like chaperone protein that is able to interact with TGBp2 of Potato mop-top virus (PMTV) (Haupt et al. 2005). The homology of this chaperone protein to endosomal trafficking proteins in the receptor-mediated endocytosis-8 (RME8) family suggests that the TGBp2-assisted virus transport is mediated by the chaperone protein. However, it remains unclear whether the conserved Cys residues of TGBp2 are involved in the interaction with the host proteins.

The delayed cell-to-cell movement and severely inhibited systemic movement of the mutant BaMV (Figs. 5, 6, 7, and 8) were similar to those seen for the C-terminal deletion of $\mathrm{Po}$ tato virus $X$ (PVX) TGBp3 (Ju et al. 2008). This indicates that both TGBp2 and TGBp3 play roles in the cell-to-cell and sys- temic movement of potexviruses. However, the differential effect of the same Cys-to-Ala substitutions in TGBp2 on the cell-to-cell and systemic movement of BaMV suggests that the TGBp2- and TGBp3-dependent mechanism of the phloem import of viral RNA is different from that of the cell-to-cell transport of viral RNA. To carry out systemic movement, the viral nucleic acids have to enter into the companion cells (CC) (Carrington et al. 1996; Nelson and Van Bel 1998) before entry into the sieve elements (SE) of phloem, where the viral RNP can further move into the developing organs (Ryabov et al. 1999). Based on the membrane association of TGBp2 and enucleating of SE, we think that TGBp2 may ultimately reside in membrane structures of $\mathrm{CC}$, rather than in SE, to assist the virus transport. We also propose that the membrane-associated mutant TGBp2 is inefficient to interact with certain phloem proteins to assist viral RNA exchange through the pore plasmodesmal units between $\mathrm{CC}$ and $\mathrm{SE}$ of the phloem in a way similar to the transport of small RNA (Yoo et al. 2004) as well as sense and antisense RNA (Xoconostle-Cazares et al. 1999) by the phloem proteins. Our observation of a very weak green fluorescence spread in the phloem of the petiole along the route of systemic infection by the mutant BaMV may support this idea (Figs. 7 and 8). To confirm this idea, the phloem proteins which have the potential to interact with TGBp2 should be identified. In fact, the assistance of PD-mediated macromolecular exchange between $\mathrm{CC}$ and SE by the phloem proteins has been documented (Haywood et al. 2002).

The facts that substitutions of the highly conserved Cys residues at the C-terminal tail of TGBp2 for Ala render the cell-tocell movement of BaMV delayed (Fig. 4) and the systemic movement of BaMV severely inhibited (Figs. 5, 6, 7, and 8), and that deletion or substitution of the highly conserved amino acid residues in the central loop of TGBp2 inhibits the cell-tocell movement of PVX (Ju et al. 2007), indicate that TGBp2 is a protein of two functional domains. The central loop participates in the formation of ER-derived transport-competent granular vesicles while the C-terminal tail exposed on the outer surface of the granular vesicles is involved in both the cell-to-cell and systemic movement of potexviruses.

\section{MATERIALS AND METHODS}

\section{Construction of the infectious clones of BaMV.}

The infectious clones pGC109A, pGC112A, and pGC109, $112 \mathrm{~A}$ of the mutant BaMV were derived from the plasmid pCBG using the QuikChange Site-Directed Mutagenesis Kit (Stratagene, La Jolla, CA, U.S.A.). The pCBG plasmid was derived from the WT BaMV clone, $\mathrm{pCB}$, by insertion of the gfp gene (Lin et al. 2004). The pGC109A and pGC112A plasmids contain the Cys-109-Ala and Cys-112-Ala substitution in TGBp2, respectively; whereas pGC109, 112A contains both substitutions in TGBp2. Primers used for construction of the mutant BaMV clones are listed in Table 1. Escherichia coli $\mathrm{DH} 5 \alpha$ and XL1-Blue were used as hosts of the plasmids.

\section{Infection of host plants with the plasmid clones of BaMV and Western blot analysis of viral CP.}

To infect $C$. quinoa and $N$. benthamiana, 2 or $3 \mu \mathrm{g}$ of each plasmid clone in a $10-\mu \mathrm{l}$ aqueous solution was inoculated onto the leaves of $C$. quinoa or $N$. benthamiana, respectively. The inoculated leaves of $C$. quinoa or $N$. benthamiana were examined 6 and 17 dpi, respectively, with a KODAK Image Station 2000MM using 465-nm excitation and 535-nm wide-angle (WA) emission filtering. The systemic leaves of $N$. benthamiana were examined 23 and 32 dpi using the same KODAK Image Station. To confirm BaMV infection, $0.2 \mathrm{~g}$ of inoculated or systemic leaves were ground in liquid nitrogen before adding 500 
$\mu \mathrm{l}$ of extraction buffer $(50 \mathrm{mM}$ Tris- $\mathrm{HCl}, \mathrm{pH} 8.0 ; 10 \mathrm{mM} \mathrm{KCl}$; $10 \mathrm{mM} \mathrm{MgCl} 2 \cdot 6 \mathrm{H}_{2} \mathrm{O} ; 1 \mathrm{mM}$ EDTA, $20 \%$ glycerol; $2 \%$ sodium dodecyl sulfate [SDS]; and $10 \% \beta$-mecaptoethanol). The proteins in the leaf extract were separated in a $12 \%$ SDS polyacrylamide gel, blotted onto a polyvinylidene diflouride membrane, and analyzed with antibody against the $\mathrm{CP}$ (anti-CP).
Subcellular fractionation of the BaMV-infected tissues and immunological analyses of TGBp2.

The membrane fraction (P30) of $N$. benthamiana leaves inoculated with the sap from the WT or mutant BaMV-infected leaves was prepared as previously described (Hsu et al. 2008). To analyze TGBp2, the P30 fraction prepared from $5 \mathrm{~g}$ of the
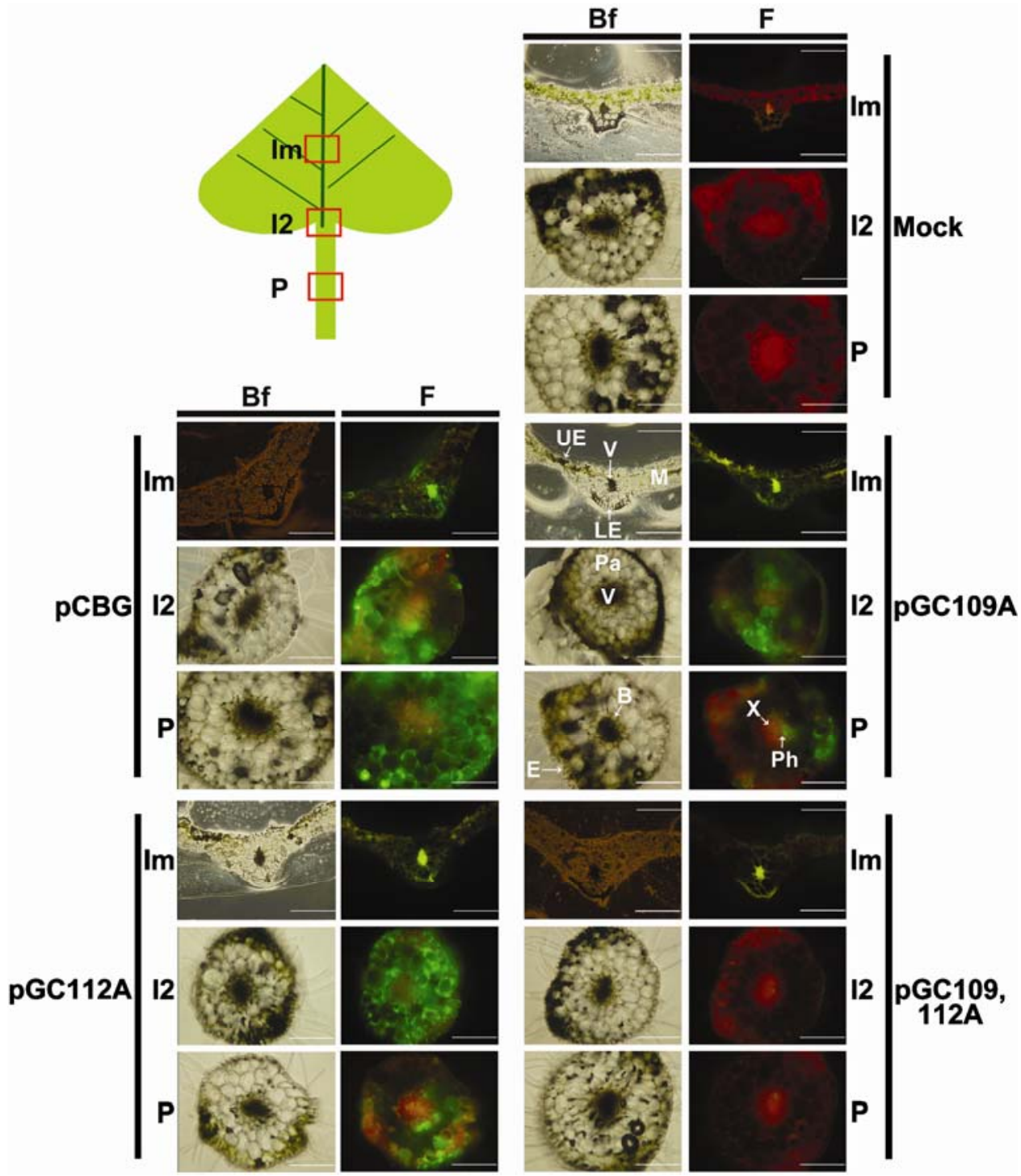

Fig. 8. Green fluorescent protein signal in the transverse sections of the midrib and surrounding mesophyll, the junction between the blade and petiole, and the midway petiole of the Nicotiana benthamiana leaves inoculated with Bamboo mosaic virus (BaMV). The infectious plasmid clones of BaMV used to inoculate the leaves of $N$. benthamiana are shown in the right or left margin. Mock indicates the inoculation of $N$. benthamiana leaves with water. The locations of $N$. benthamiana leaf being analyzed are shown in the top left margin. Im, the midrib and surrounding mesophyll of the blade; I2, the free-hand section of the junction between the blade and petiole; $\mathrm{P}$, the free-hand section of the midway petiole. Two different images were taken; $\mathrm{Bf}$ is the bright-field image and $\mathrm{F}$ is the fluorescence image. The tissues in leaves inoculated with pGC109A are labeled. M, mesophyll; B, bundle sheath; V, vascular system; Pa, parenchyma; E, epidermis; UE, upper epidermis; LE, lower epidermis; X, xylem; Ph, phloem. The white bars shown in the bottom right corner of all images represent $500 \mu \mathrm{m}$.

Table 1. Oligonucleotide primers used in this study

\begin{tabular}{|c|c|c|}
\hline Primer & Sequence $\left(5^{\prime}\right.$ to $\left.3^{\prime}\right)$ & Purpose \\
\hline C109Af & GAATCTATGCGCCCCTCGCATTGCATTGTCACCGGAATC & C109A substitution \\
\hline $\mathrm{C} 109 \mathrm{Ar}$ & GATTCCGGTGACAATGCAATGCGAGGGGCGCATAGATTC & C109A substitution \\
\hline C112Af & GCCCCTCTGCTTGCATGCACACCGGAATCACCCAC & C112A substitution \\
\hline $\mathrm{C} 112 \mathrm{Ar}$ & GTGGGTGATTCCGGTGTGCATGCAAGCAGAGGGGC & C112A substitution \\
\hline C109, 112Af & CTAGAATCTATGCGCCCCTCGCATTGCATGCACACCGGAATCACCCACC & C109, 112A substitution \\
\hline $\mathrm{C} 109,112 \mathrm{Ar}$ & GGTGGGTGATTCCGGTGTGCATGCAATGCGAGGGGCGCATAGATTCTAG & C109, 112A substitution \\
\hline Tn836 & $\mathrm{T}_{15}$ CTTAAGCAGCT & Reverse transcription \\
\hline $5053 \mathrm{f}$ & TACCCTTCCACACACCGGCG & Amplification nt 5035-5382 \\
\hline $5382 \mathrm{r}$ & GGGCAGATGCTGTTGAAG & Amplification nt 5035-5382 \\
\hline P2 Seqf & AGGTACGTGGACGGCACC & Sequencing \\
\hline
\end{tabular}


inoculated leaves was ground with a $1-\mathrm{ml}$ buffer $(10 \mathrm{mM}$ Tris$\mathrm{HCl}, \mathrm{pH} 7.5 ; 10 \mathrm{mM} \mathrm{KCl} ; 5 \mathrm{mM} \mathrm{MgCl}$; $1 \%$ [vol/vol] 2-mercaptoethanol; $5 \mathrm{mM}$ dithiothreitol; $2 \mathrm{mM}$ aminocaproic acid; 2 $\mathrm{mM}$ phenylmethylsulfonyl fluoride; and 1\% Igepal CA-630) and delipidated as previously depicted (Hsu et al. 2008). The sample was then subjected to tricine SDS polyacrylamide gel electrophoresis and immunological analysis. The protocols used for immunological analysis of TGBp 2 and preparation of the precleaned anti-TGBp2 are similar to those described in a previous article (Hsu et al. 2008).

\section{RT-PCR, TA cloning, and DNA sequencing.}

Total RNAs were prepared from the inoculated leaves of $C$. quinoa and $N$. benthamiana as previously described (Lin et al. 1996). First-strand cDNA synthesis was performed with $\mathrm{Su}$ perScript II reverse transcriptase (Invitrogen) and Tn836 primer (Table 1). The full-length cDNAs were subjected to PCR using the forward primer (5053f) and reverse primer (5382r) (Table 1), and the cDNA products were cloned into the yT\&A TA cloning vector (Yeastern Biotech Co., Ltd., Taipei, Taiwan). The insert DNA in the plasmid was amplified by PCR and sequenced using an ABI PRISM 3100 sequencer.

\section{Infection of protoplasts with the plasmid clone of BaMV and detection of viral RNA.}

Protoplasts were prepared from $N$. benthamiana leaves as previously described (Cheng and Tsai 1999). The protoplasts (approximately 2 to $4 \times 10^{5}$ ) were inoculated with $15 \mu \mathrm{g}$ of infectious plasmid and harvested $48 \mathrm{~h}$ postinoculation (hpi). The procedure used for the analysis of viral RNA by Northern blot was described previously (Cheng and Tsai 1999). The levels of full-length genomic RNA of the WT and each mutant BaMV on the blot were normalized with that of 28S rRNA. The relative replication efficiency of each mutant BaMV was reported as the percentage of full-length genomic RNA of each mutant BaMV relative to that of the WT after normalization.

\section{Analyses of cell-to-cell and systemic movement of BaMV.}

The cell-to-cell movement of the WT and mutant BaMV within the epidermal cells of $C$. quinoa were examined with an Olympus BX51 epifluorescence microscope using a filter set consisting of an excitation filter (460 to $490 \mathrm{~nm}$ ), a dichromatic mirror $(500 \mathrm{~nm})$, and an emission filter $(520 \mathrm{~nm})$ equipped with an Olympus DP71 camera (Olympus, Tokyo). In short, $2 \mu \mathrm{g}$ of the infectious plasmid clone of BaMV in a $10-\mu \mathrm{l}$ aqueous solution was inoculated onto the leaves of $C$. quinoa. At 6 dpi, the inoculated leaves were examined with a KODAK Image Station 2000MM. Green fluorescent spots on each inoculated leaf were counted and their diameters were measured with an Olympus BX51 epifluorescence microscope.

The systemic movement of BaMV in different parts of $N$. benthamiana was examined with an Olympus BX51 epifluorescence microscope. In brief, $3 \mu \mathrm{g}$ of the plasmid clone of $\mathrm{BaMV}$ in a $10-\mu \mathrm{l}$ aqueous solution was inoculated onto the leaves of $N$. benthamiana. The spread of GFP fluorescence in inoculated leaves, petioles, stems, and upper uninoculated leaves (systemic leaves) of $N$. benthamiana was monitored using a handheld UV lamp and examined 15, 20, and 25 dpi with an Olympus BX51 epifluorescence microscope.

The ability of the WT and mutant BaMV to move from mesophyll to the vascular system of midrib of the inoculated $N$. benthamiana leaves was investigated 20 dpi. A small area (2 by $7 \mathrm{~mm}$ ) of the leaf, including the midrib and surrounding mesophyll of the blade, was cut, embedded vertically in a tissue freezing medium (Jung), and frozen at $-16^{\circ} \mathrm{C}$ for $30 \mathrm{~min}$. Transverse sections with a thickness of $15 \mu \mathrm{m}$ were cut out with a cryostat microtome (Model OTF/F2; Bright Instruments
Co Ltd., Huntington, U.K.) and adhered to a slide coated with subbing solution (5\% gelatin and $0.05 \%$ chromium potassium sulfate). The transverse sections were then examined with an Olympus BX51 epifluorescence microscope.

\section{ACKNOWLEDGMENTS}

This research was supported by National Science Council of the Republic of China grant NSC 89-2311-B-005-054, NSC 94-2311-2752-B-005011-PAE, and NSC96-2752-B-005-009-PAE. We thank C.-H. Lin for the assistance in using microtome.

\section{LITERATURE CITED}

Angell, S. M., Davies, C., and Baulcombe, D. C. 1996. Cell-to-cell movement of potato virus $\mathrm{X}$ is associated with a change in the size-exclusion limit of plasmodesmata in trichome cells of Nicotiana clevelandii. Virology 216:197-201.

Arce-Johnson, P., Kahn, T. W., Reimann-Philipp, U., Rivera-Bustamante, R., and Beachy, R. N., 1995. The amount of movement protein produced in transgenic plants influences the establishment, local movement, and systemic spread of infection by movement protein-deficient tobacco mosaic virus. Mol. Plant-Microbe Interact. 8:415-423.

Atabekov, J. G., Rodionova, N. P., Karpova, O. V., Kozlovsky, S. V., and Poljakov, V. Y. 2000. The movement protein-triggered in situ conversion of Potato virus $X$ virion RNA from a nontranslatable into a translatable form. Virology 271:259-263.

Bayne, E. H., Rakitina, D. V., Morozov, S. Yu., and Baulcombe, D. C. 2005. Cell-to-cell movement of potato potexvirus $\mathrm{X}$ is dependent on suppression of RNA silencing. Plant J. 44:471-482.

Bucher, G. L., Tarina, C., Heinlein, M., Di Serio, F., Meins, F., and Iglesias, V. A. 2001. Local expression of enzymatically active class I $\beta$-1,3-glucanase enhances symptoms of TMV infection in tobacco. Plant J. 28:361-369.

Carrington, J. C., Kasschau, K. D., Mahajan, S. K., and Schaad, M. C. 1996. Cell-to-cell and long-distance transport of viruses in plants. Plant Cell 8:1669-1681.

Chang, B. Y., Lin, N. S., Liou, D. Y., Chen, J. P., Liou, G. G., and Hsu, Y. H. 1997. Subcellular localization of the $28 \mathrm{kDa}$ protein of the triplegene-block of bamboo mosaic potexvirus. J. Gen. Virol. 78:11751179 .

Chapman, S., Hills, G., Watts, J., and Baulcombe, D. 1992. Mutational analysis of the coat protein gene of potato virus $\mathrm{X}$ : Effects on virion morphology and viral pathogenicity. Virology 191:223-230.

Cheng, C. P., and Tsai, C. H. 1999. Structural and functional analysis of the untranslated region of bamboo mosaic potexvirus genomic RNA. J. Mol. Biol. 288:555-565.

Citovsky, V., Knorr, D., Schuster, G., and Zambryski, P. 1990. The P30 movement protein of tobacco mosaic-virus is a single-strand nucleicacid binding protein. Cell 60:637-647.

Citovsky, V., Wong, M. L., Shaw, A. L., Prasad, B. V. V., and Zambryski, P. 1992. Visualization and characterization of tobacco mosaic virus movement protein binding to single-stranded nucleic-acids. Plant Cell 4:397-411.

Cowan, G. H., Lioliopoulou, F., Ziegler, A., and Torrance, L. 2002. Subcellular localisation, protein interactions, and RNA binding of potato mop-top virus triple gene block proteins. Virology 298:106-115.

Davies, C., Hills, G., and Baulcombe, D. C. 1993. Subcellular localization of the 25-kDa protein encoded in the triple gene block of potato virus X. Virology 197:166-175.

Forster, R. L. S., Beck, D. L., Guilford, P. J., Voot, D. M., van Dolleweerd, C. J., and Andersen, M. T. 1992. The coat protein of white clover mosaic potexvirus has a role in facilitating cell-to-cell transport in plants. Virology 191:480-484.

Fridborg, I., Grainger, J., Page, A., Coleman, M., Findlay, K., and Angell, S. 2003. TIP, a novel host factor linking callose degradation with the cell-to-cell movement of potato virus X. Mol. Plant-Microbe Interact. 16:132-140.

Gorshkova, E. N., Erokhina, T. N., Stroganova, T. A., Yelina, N. E., Zamyatnin, A. A., Jr., Kalinina, N. O., Schiemann, J., Solovyev, A. G., and Morozov, S. Yu. 2003. Immunodetection and fluorescent microscopy of transgenically expressed hordeivirus TGBp3 movement protein reveals its association with endoplasmic reticulum elements in close proximity to plasmodesmata. J. Gen. Virol. 84:985-994.

Haupt, S., Cowan, G. H., Ziegler, A., Roberts, A. G., Oparka, K. J., and Torrance, L. 2005. Two plant-viral movement proteins traffic in the endocytic recycling pathway. Plant Cell 17:164-181. 
Haywood, V., Kragler, F., and Lucas, W. J. 2002. Plasmodesmata: Pathways for protein and ribonucleoprotein signaling. Plant Cell 14:S303S325

Hsu, H. T., Hsu, Y. H., Bi, I. P., Lin, N. S., and Chang, B. Y. 2004. Biological functions of the cytoplasmic TGBp1 inclusions of bamboo mosaic potexvirus. Arch. Virol. 149:1027-1035.

Hsu, H. T., Chou, Y. L., Tseng, Y. H., Lin, Y. H., Lin, T. M., Lin, N. S., Hsu, Y. H., and Chang, B. Y. 2008. Topological properties of the triple gene block protein 2 of Bamboo mosaic virus. Virology 379:1-9.

Iglesias, V. A., and Meins, F. 2000. Movement of plant viruses is delayed in a $\beta$-1,3-glucanase-deficient mutant showing a reduced plasmodesmal size exclusion limit and enhanced callose deposition. Plant J. 21:157166

Ju, H. J., Samuels, T. D., Wang, Y. S., Blancaflor, E., Payton, M., Mitra, R., Krishnamurthy, K., Nelson, R. S., and Verchot-Lubicz, J. 2005. The Potato virus $X$ TGBp2 movement protein associates with endoplasmic reticulum-derived vesicles during virus infection. Plant Physiol. 138:1877-1895.

Ju, H. J., Brown, J. E., Ye, C. M., and Verchot-Lubicz, J. 2007. Mutations in the central domain of Potato virus $X$ TGBp2 eliminate granular vesicles and virus cell-to-cell trafficking. J. Virol. 81:1899-1911.

Ju, H. J., Ye, C. M., and Verchot-Lubicz, J. 2008. Mutational analysis of PVX TGBp3 links subcellular accumulation and protein turnover. Virology 375:103-117.

Kalinina, N. O., Fedorkin, O. N., Samuilova, O. V., Maiss, E., Korpela, T., Morozov, S., and Atabekov, J. G. 1996. Expression and biochemical analyses of the recombinant potato virus $X 25 \mathrm{~K}$ movement protein. FEBS (Fed. Eur. Biochem. Soc.) Lett. 397:75-78

Kalinina, N. O., Rakitina, D. V., Solovyev, A. G., Schiemann, J., and Morozov, S. Yu. 2002. RNA helicase activity of the plant virus movement proteins encoded by the first gene of the triple gene block. Virology 296:321-329.

Krishnamurthy, K., Heppler, M., Mitra, R., Blancaflor, E., Payton, M., Nelson, R. S., and Verchot-Lubicz, J. 2003. The Potato virus X TGBp3 protein associates with the ER network for virus cell-to-cell movement. Virology 309:135-151.

Lin, M. K., Chang, B. Y., Liao, J. T., Lin, N. S., and Hsu, Y. H. 2004 Arg-16 and Arg-21 in the N-terminal region of the triple-gene-block protein 1 of Bamboo mosaic virus are essential for virus movement. J. Gen. Virol. 85:251-259.

Lin, N. S., Lee, Y. S., Lin, B. Y., Lee, C. W., and Hsu, Y. H. 1996. The open reading frame of bamboo mosaic potexvirus satellite RNA is not essential for its replication and can be replaced with a bacterial gene. Proc. Natl. Acad. Sci. U.S.A. 93:3138-3142.

Liou, D. Y., Hsu, Y. H., Wung, C. H., Wang, W. H., Lin, N. S., and Chang, B. Y. 2000. Functional analyses and identification of two arginine residues essential to the ATP-utilizing activity of the triple gene block protein 1 of bamboo mosaic potexvirus. Virology 277:336-344.

Lough, T. J., Shash, K., Xoconostle-Cazares, B., Hofstra, K. R., Beck, D. L., Balmori, E., Forster, R. L., and Lucas, W. J. 1998. Molecular dissection of the mechanism by which potexvirus triple gene block proteins mediate cell-to-cell transport of infectious RNA. Mol. Plant-Microbe Interact. 11:801-814.

Lough, T. J., Netzler, N. E., Emerson, S. J., Sutherland, P., Carr, F., Beck, D. L., Lucas, W. J., and Forster, R. L. S. 2000. Cell-to-cell movement of potexviruses: Evidence for a ribonucleoprotein complex involving the coat protein and the first triple gene block protein. Mol. Plant-Microbe Interact. 13:962-974.

Mitra, R., Krishnamurthy, K., Blancaflor, E., Payton, M., Nelson, R. S., and Verchot-Lubicz, J. 2003. The Potato virus $X$ TGBp2 protein association with the endoplasmic reticulum plays a role in but is not sufficient for viral cell-to-cell movement. Virology 312:35-48.

Morozov, S. Yu., and Solovyev, A. G. 2003. Triple gene block: Modular design of a multifunctional machine for plant virus movement. J. Gen. Virol. 84:1351-1366.

Morozov, S. Yu., Dolja, V. V., and Atabekov, J. G. 1989. Probable reassortment of genomic elements among elongated RNA-containing plant viruses. J. Mol. Evol. 29:52-62.

Morozov, S. Yu., Solovyev, A. G., Kalinina, N. O., Fedorkin, O. N., Samuilova, O. V., Schiemann, J., and Atabekov, J. G. 1999. Evidence for two nonoverlapping functional domains in the potato virus $\mathrm{X} 25 \mathrm{~K}$ movement protein. Virology 260:55-63.

Nelson, R. S., and Van Bel, A. 1998. The mystery of virus trafficking into, through, and out of vascular tissue. Prog. Bot. 59:476-533.

Petty, I. T. D., French, R., Jones, R. W., and Jackson, A. O., 1990. Identification of barley stripe mosaic virus genes involved in viral RNA replication and systemic movement. EMBO (Eur. Mol. Biol. Organ.) J. 9:3453-3457.

Quillet, L., Guilley, H., Jonard, G., and Richards, K. 1989. In vitro synthesis of biologically active beet necrotic yellow vein virus RNA. Virology 172:293-301

Rouleau, M., Smith, R. J., Bancroft, J. B., and Mackie, G. A. 1994. Purification, properties, and subcellular localization of foxtail mosaic potexvirus 26-kDa protein. Virology 204:254-265.

Ryabov, E. V., Robinson, D. J., and Taliansky, M. E. 1999. A plant virusencoded protein facilitates long-distance movement of heterologous viral RNA. Proc. Natl. Acad. Sci. U.S.A. 96:1212-1217.

Solovyev, A. G., Savenkov, E. I., Agranovsky, A. A., and Morozov, S. Yu. 1996. Comparisons of the genomic cis-elements and coding regions in RNA $\beta$ components of the hordeiviruses barley stripe mosaic virus, lychnis ringspot virus, and Poa semilatent virus. Virology 219:9-18

Solovyev, A. G., Stroganova, T. A., Zamyatnin, A. A., Jr., Fedorkin, O. N., Schiemann, J., and Morozov, S. Yu. 2000. Subcellular sorting of small membrane-associated triple gene block proteins: TGBp3-assisted targeting of TGBp2. Virology 269:113-127.

Voinnet, O., Lederer, C., and Baulcombe, D. C. 2000. A viral movement protein prevents spread of the gene silencing signal in Nicotiana benthamiana. Cell 103:157-167.

Wolf, S., Deom, C. M., Beachy, R., and Lucas, W. J. 1991. Plasmodesmatal function is probed using transgenic tobacco plants that express a virus movement protein. Plant Cell 3:593-604.

Wung, C. H., Hsu, Y. H., Liou, D. Y., Huang, W. C., Lin, N. S., and Chang, B. Y. 1999. Identification of the RNA-binding sites of the triple gene block protein 1 of bamboo mosaic potexvirus. J. Gen. Virol. 80:1119-1126.

Xoconostle-Cazares, B., Xiang, Y., Ruiz-Medrano, R., Wang, H. L., Monzer, J., Yoo, B. C., McFarland, K. C., Franceschi, V. R., and Lucas, W. J. 1999. Plant paralog to viral movement protein that potentiates transport of mRNA into the phloem. Science 283:94-98.

Yoo, B. C., Kragler, F., Varkonyi-Gasic, E., Haywood, V., Archer-Evans, S., Lee, Y. M., Lough, T. J., and Lucas, W. J. 2004. A systemic small RNA signaling system in plants. Plant Cell 16:1979-2000.

Zamyatnin, A. A., Jr., Solovyev, A. G., Sablina, A. A., Agranovsky, A. A., Katul, L., Vetten, H. J., Schiemann, J., Hinkkanen, A. E., Lehto, K., and Morozov, S. Yu. 2002. Dual-colour imaging of membrane protein targeting directed by Poa semilatent virus movement protein TGBp3 in plant and mammalian cells. J. Gen. Virol. 83:651-662. 